РОЛЬ ФАХІВЦІВ СЕСТРИНСЬКОЇ СПРАВИ В ОРГАНІЗАЦІЇ ПЕРВИННОЇ ПРОФІЛАКТИКИ ВІЛ-ІНФЕКЦІЇ СЕРЕД СТУДЕНТСЬКОЇ МОЛОДІ

\title{
THE ROLE OF NURSING SPECIALISTS IN THE ORGANIZATION OF PRIMARY PREVENTION OF HIV INFECTION AMONG STUDENT YOUTH
}

здійснено загальну характеристику специсріки просресійної діяльності орахівців сестринської справи в розрізі здійснення первинної профрілактики ВІЛ-інфрекції серед студентської молоді. Узагальнено, що, незважаючи на досягнуті успіхи, ВІЛ-інфекція залишається національною загрозою для багатьох країн світу й усього світового співтовариства на глобальному рівні, а боротьба з вірусом, що викликає це захворювання, - одним із найбільш актуальних завдань, що стоять перед сучасними вченими. Катастрофрічне поширення вірусу імунодефіциту людини (ВІЛ) в кінці XX cm. призвело до того, що це захворювання набуло розмірів пандемії. Підсумовано, що первинна профілактика, спрямована на студентську молодь, полягає у мінімізації впливу чинників ризику. Первинна профрілактика включає тестування донорської крові на ВІЛ, просрілактику наркоманії та зловживання алкоголем, просвіту та навчання з метою популяризації безпечних статевих відносин, пропаганди безпечної ін'єкційної практики та ін.

Велике значення в попередженні зараження ВІЛ-інфрекцією має інфрормування молодшим медичним персоналом студентської молоді про захворювання, особливості шляхів передачі і його проявів. Роль фрахівців сестринської справи в розрізі здійснення первинної профрілактики ВІЛ-інфекції серед студентської молоді полягає в організації такої роботи відповідно до вікового розвитку та когнітивної обізнаності кожного студента в окресленій проблематиці. Зміст профрілактичної роботи зазвичай організовується в рамках проведення різноманітних просвітницько-інфрормаційних заходів. Зміст таких заходів передбачає поетапне розширення i поглиблення знань, розвиток компетентностей безпечної і відповідальної поведінки студентів у ситуаціях, пов'язаних із ризиком ВІЛ-інфікування, відповідно до вікових особливостей на основі обов'язкового повторення матеріалу, вивченого раніше, за допомогою активного залучення студентів у просвітницький прочес.

у рамках реалізації окреслених заходів срахівиі сестринської справи: мотивують студентів до регулярного проходження медичного огляду на ВІЛ-інфекцію, особливо за наявності високого ризику інфьікування ВІЛ; забезпечують максимальне охоплення медичним оглядом на ВІЛ-інфрекцію студентів, щодо яких планується здійснення діагностичних заходів або лікування із застосуванням інвазивних маніпуляцій, або хірургічних втручань, що супроводжуються високим ризиком передачі ВІЛ-інфекції, та ін.
Ключові слова: фрахівці сестринської справи, студенти, первинна профрілактика просвітницька діяльність, інформаційна діяльність, ВІЛ-інфекція.

General characteristic of the specifics of professional activities of nursing specialists in terms of the implementation of primary prevention of HIV infection among student youth has been done. It has been generalized that despite the progress made, HIV infection remains a national threat to many countries and the whole world community at the global level, and the fight against the virus that causes this disease is one of the most urgent tasks facing modern scientists. A catastrophic spread of human immunodeficiency virus (HIV) in the end of the XXth century led to the fact that this disease has reached the size of a pandemic. It has been summarized that primary prevention, directed to student youth, is to minimize the impact of risk factors. Primary prevention contains testing of donor blood for HIV, prevention of drug addiction and alcohol abuse, education and study in order to promote safe sexual relations, promotion of safe injection practices, etc. Informing junior medical staff of student youth about the disease, the peculiarities of the ways of transmission and its manifestations is of great importance in the prevention of HIV infection. The role of nursing specialists in terms of caring out primary prevention of HIV infection among student youth is in the organization of such work in accordance with the age development and cognitive awareness of each student in the outlined issues. The content of preventive work is usually organized in the framework of various educational and informational activities. The essence of such work involves the gradual expansion and deepening of knowledge, development of competencies of safe and responsible behavior of students in situations, related to the risk of HIV infection according to age features on the basis of obligatory repetition of the material studied earlier, by means of active involvement of students in educational process.

As part of the implementation of the described activities, nursing specialists: motivate students to undergo regular medical examinations for HIV infection, especially in the presence of a high risk of HIV infection; ensure maximum coverage by medical examination for HIV infection of students for whom it is planned to carry out diagnostic measures, or treatment with invasive manipulations, or surgical interventions, which are accompanied by a high risk of transmission of HIV infection, etc.

Key words: nursing specialists, students, primary prevention, educational activities, informational activities, HIV infection.

Рівненської обласної ради

Постановка проблеми в загальному вигляді. Медичні сестри у світі нині $€$ найчисельнішим «загоном» працівників охорони здоров'я, і саме на них лягає основне навантаження щодо контролю за багатьма захворюваннями. Як йдеться в «Етич- ному кодексі медичних сестер», «...у медичної сестри є чотири основні обов'язки: пропагувати здоровий спосіб життя, запобігати розвитку хвороб, повертати здоров'я хворим і полегшувати їхні страждання...» [4]. 
Що стосується ВІЛ-інфрекції - це суспільне явище, що має яскраво виражені соціальні та поведінкові характеристики. Так, у рамках первинної профрілактики поширення ВІЛ-інфрекції молодші медичні сестри освічують населення, запобігають поширенню інфекції, беруть участь у лікуванні, допомагають дотримуватися необхідного режиму і полегшують страждання хворих, надаючи їм психологічну або іншу підтримку залежно від конкретних потреб кожного хворого, а так само соціально інфрормують молодь, зокрема й студентську, щодо заходів особистого захисту в умовах стрімкого поширення окресленої інфекції.

Незважаючи на досягнуті успіхи, ВІЛ-інфекція залишається національною загрозою для багатьох країн світу й усього світового співтовариства на глобальному рівні, а боротьба $з$ вірусом, що викликає це захворювання, - одним із найбільш актуальних завдань, що стоять перед сучасними вченими. Катастрофрічне поширення вірусу імунодефріциту людини (ВІЛ) у кінці XX ст. призвело до того, що це захворювання набуло розмірів пандемії. За даними ЮНЕЙдС, станом на грудень 2019 р. пандемія ВІЛ-інфекції починаючи 3 1981 р. забрала життя понад 39 млн людей, і ще близько 35 млн нині заражені ВІЛ-1 [13, с. 1004]. При цьому, за даними Європейського бюро ВООЗ, ВІЛ-інфекція залишається однією з головних проблем в Європейському регіоні, а на Сході Європи триває розвиток епідемії найшвидшими темпами у світі: тоді як на глобальному рівні число нових випадків ВІЛ-інфрекції скорочується, у країнах Східної Європи і Центральної Азії воно продовжує рости [13, с. 1005].

На жаль, епідемія ВІЛ-інфрекції продовжує розвиватися і на території України [1], тому нині важливим вектором руху протидії поширенню ВІЛ-інсрекції $€$ первинна профрілактика серед молоді, активними учасниками якої є молодші медичні сестри.

Аналіз останніх досліджень і публікацій. Проблема вивчення особливостей професійної діяльності та фрахової підготовки знаходиться в полі наукових пошуків сучасних дослідників [11]. Зокрема, М. Демянчук [2] виокремив вектори професійної комунікації майбутніх фрахівців сестринської справи, у тому числі з ВІЛ-інфрікованими пацієнтами. О. Маркович звернув увагу на використання педагогічних технологій у процесі підготовки коледжами медичних сестер із метою розвитку здатності студентів до надання психологічної допомоги хворим на вірус імунодефіциту [9]. Своєю чергою, А. Шемшура висвітлив роль сестринського персоналу в реалізації заходів із протидії епідемії ВІЛ-інфрекції [13]. Схожий вектор дослідження вибрала Н. Низова, котра вивчила роль первинної ланки медико-санітарної допомоги населенню в системі протидії поширенню ВІЛ-інфекції статевим шляхом [10].
Привертають увагу висновки О. Децика щодо впливу соціального, родинного та навчального оточення на фрормування превентивної обізнаності молоді щодо ВІЛ-інфекції [3]; організації роботи медичної сестри з ВІЛ-інфрікованими пацієнтами [6]; ставлення медичних сестер до ВІЛ-інфрікованих і хворих на СНІД [8]; особливостей медичного догляду, психологічної допомоги, соціального супроводу дітей та молоді 3 ВІЛ-інфекцією [12]. Серед плеяди сучасних науковців виокремлюємо позицію К. Талалаєва, котрий наполягає на переході від лікувальної допомоги до предиктивної медицини з метою запобігання поширенню ВІЛ-інфекції [12].

Разом із тим, питання виокремлення ролі фрахівців сестринської справи у здійсненні первинної профрілактики ВІЛ-інфекції серед студентської молоді не знайшло належного відображення в сучасних наукових доробках провідних дослідників.

Мета статті. Метою статті вважаємо загальну характеристику специфіки професійної діяльності фрахівців сестринської справи в розрізі здійснення первинної профрілактики ВІЛ-інфекції серед студентської молоді.

Виклад основного матеріалу. Первинна просрілактика, спрямована на студентську молодь, полягає у мінімізації впливу чинників ризику. Первинна профрілактика включає тестування донорської крові на ВІЛ, профрілактику наркоманії та зловживання алкоголем, просвіту та навчання з метою популяризації безпечних статевих відносин, пропаганди безпечної ін'єкційної практики та ін.

Велике значення у попередженні зараження ВІЛ-інфекцією має інорормування молодшим медичним персоналом студентської молоді про захворювання, особливості шляхів передачі і його проявів. Проведені в останні роки дослідження в Україні дали змогу констатувати, що загальний рівень інорормованості студентської молоді залишається недостатнім, і навіть за наявності знань про механізми і шляхи передачі захворювання часто у молодих людей відсутня настороженість у плані можливого зараження.

Недооцінка ризику зараження, своєю чергою, загрожує нехтуванням заходами захисту. Згідно 3 Державною стратегією, з 2016 р. пріоритетним напрямом первинної профрілактики стає інфрормаційно-пропагандистська діяльність, у тому числі й молодших медичних сестер, із питань запобігання поширенню ВІЛ-інфекції [8]. За наявними даними, інформаційні кампанії серед студентської молоді можуть бути корисними у стримуванні епідемії ВІЛ/СНІДу.

Молодь є групою населення 3 високою ймовірністю зараження ВІЛ-інфрекцією й основною цільовою групою профрілактичних заходів, що проводяться освітніми установами. Освітня установа має низку унікальних можливостей для проведення 
профрілактичної роботи молодшими медичними сестрами. Разом із тим первинна профілактична робота має величезний вплив на фрормування і розвиток особистості студента, адже базується на кваліфрікованій організаційній та методично-просвітницькій діяльності не лише педагогів і психологів, а й молодших медичних сестер, котрі здатні забезпечити ведення в освітній установі ефективної систематичної профрілактичної роботи.

Початок профрілактичної діяльності стосовно запобігання поширенню ВІЛ-інфекції молодшої медичної сестри в закладах середньої та вищої освіти повинен збігатися з початком навчання студента, оскільки ефективною в напрямі профрілактики ВІЛ може вважатися не стільки інфрормаційнопросвітницька робота, скільки цілеспрямована діяльність молодших медичних сестер щодо фрормування цінностей, умінь і навичок студентів щодо ведення здорового і безпечного способу життя.

Уважаємо, що роль фрахівців сестринської справи в розрізі здійснення первинної профрілактики ВІЛ-інфекції серед студентської молоді полягає в організації такої роботи відповідно до вікового розвитку та когнітивної обізнаності кожного студента в окресленій проблематиці. Зміст профрілактичної роботи зазвичай організовується в рамках проведення різноманітних просвітницькоінорормаційних заходів, наприклад:

1. Круглий стіл «Профрілактика ВІЛ-інфекції шляхом пропаганди здорового способу життя».

2. Семінар-практикум «Профрілактика ВІЛ-інфекції в навчальних установах».

3. Анкетування «ВІЛ-інфрекція - це... Що ви знаєте?».

4. Поширення брошур «ВІЛ учора, сьогодні, завтра».

5. Бесіда 3 фахівцем сестринської справи на тему «Шляхи зараження».

6. Конкурсна програма «Разом проти ВІЛ».

7. Перегляди відеофільмів «Скажи: немає ВІЛ, Стоп СНІД».

8. Проведення днів пам'яті «Жертви ВІЛ».

9. Проходження медичних обстежень та ін.

Зміст таких заходів передбачає поетапне розширення і поглиблення знань, розвиток компетентностей безпечної і відповідальної поведінки студентів у ситуаціях, пов'язаних із ризиком ВІЛінорікування, відповідно до вікових особливостей на основі обов'язкового повторення матеріалу, вивченого раніше, за допомогою активного залучення студентів у просвітницький процес.

3 огляду на складність і делікатність питань, пов'язаних із поширенням ВІЛ-інфрекції серед студентської молоді, відзначимо, що молодша медична сестра повинна мати певний досвід їх обговорення, адже нині в освітніх закладах навчається все більше і більше молоді, котра так чи інакше вже зіштовхнулася $з$ ВІЛ-інфекцією. Так, наприклад, потенційно частина студентів може бути інорікована вірусом. Інші можуть підозрювати у себе ВІЛ, і під час перевірки на ВІЛ їхні підозри можуть підтвердитися. Тому потрібно враховувати, що ці молоді люди в першу чергу зіштовхнуться зі складними проблемами, що стосуються взаємин 3 іншими людьми, навчання або роботи.

Профрілактична робота фрахівців сестринської справи в студентських групах повинна бути спрямована на формування і розвиток захисних чинників, що перешкоджають ВІЛ-інфрікуванню. Це стосується як біологічних (фрізіологічних), так і психологічних і соціальних чинників. Провідними принципами первинної профрілактичної роботи $€$ програми фрормування здорового способу життя молоді, їхніх життєвих навичок, у тому числі комунікативних, а також підготовка до складних життєвих обставин.

У проведенні профрілактичної роботи у студентських групах доцільним убачається поєднання дидактичних та інтерактивних методів в умовах додаткової освіти та дозвільної діяльності. Велике значення для успішної профрілактики мають стимуляція, заохочення, підтримка самостійної активності студентів. Організаційними фрормами діяльності медичних сестер з попередження ВІЛінфікування у середніх та вищих закладах освіти можуть бути:

а) заняття $з$ профрілактики ВІЛ-інфрекції;

б) консультації, організовувані для студентів. Найбільш масовою фрормою профрілактичної роботи є групові заняття, у рамках яких студенти можуть отримати більш детальну інформацію з проблем ВІЛ/СНІДу, збагатити вміння безпечної і відповідальної поведінки.

У рамках реалізації окреслених заходів фрахівці сестринської справи:

- мотивують студентів до регулярного проходження медичного огляду на ВІЛ-інфекцію, особливо за наявності високого ризику інфікування ВІЛ;

- забезпечують максимальне охоплення медичним оглядом на ВІЛ-інфрекцію студентів, щодо яких планується здійснення діагностичних заходів або лікування із застосуванням інвазивних маніпуляцій, або хірургічних утручань, що супроводжуються високим ризиком передачі ВІЛ-інфекції;

- проводять медичний огляд на ВІЛ-інфекцію всіх пацієнтів, які звернулися за медичною допомогою з приводу інфекцій, що передаються статевим шляхом, на вірусний гепатит типу В і С, туберкульоз;

- підвищують рівень охоплення медичним оглядом на ВІЛ-інфрекцію студентської молоді;

- забезпечують максимальну мотивацію до проходження медичного огляду на ВІЛ (з обов'язковим проведенням до- та післятестового консультування); 
- активно впроваджують сучасні підходи до тестування на ВІЛ шляхом застосування експрес-тестів, у тому числі 3 метою самостійного тестування, що дасть змогу виявити більше число молодих людей, що живуть із ВІЛ, та надати їм доступ до лікування і надання медико-санітарної допомоги на ранніх стадіях та ін.

Висновки. Підсумовано, що, згідно з останніми статистичними даними, зростає число ВІЛінфрікованих та смертей економічно активного населення у віці 15-49 років. ВІЛ/СНІД-інфекції будуть, як і раніше, впливати на систему освіти i розвиток населення України. Якщо не боротися з поширенням ВІЛ/СНІД-захворювань серед молоді, відбудеться масова втрата життів і засобів, інвестованих в освіту, що негативно позначиться на економічному розвитку країни у цілому. Нині громадськість починає розуміти, що сорера освіти повинна відігравати важливу роль у запобіганні ВІЛ-інфрікуванню, у наданні підтримки інорікованим і страждаючим людям, а також у наданні освітніх послуг, незважаючи на наслідки СНІДу. Роль молодших медичних сестер у забезпечення первинної профрілактики поширення ВІЛ-інфекції у закладах середньої та вищої освіти сьогодні зросла. У таких умовах молодша медична сестра виступає партнером держави й навчального закладу щодо організації заходів із боротьби з ВІЛ-захворюваннями.

Установлено, що дієвими заходами впливу на студентську молодь є програми інформування про ВІЛ/СНІД-захворювання, своєчасного та ефективного медичного обслуговування і пропаганди здоров'я та здорового способу життя, що проводяться в навчальних закладах. В умовах сьогодення освітні установи України володіють необхідними умовами для впровадження названих програм.

\section{БІБЛІОГРАФІЧНИЙ СПИСОК:}

1. ВІЛ-інфрекція в Україні : інфрормаційний бюлетень / за ред. В. Купіти. Київ, 2018. № 49. 121 с. URL: https://phc.org.ua/sites/default/files/users/user90/HIV in_UA_49_2018.pdf (дата звернення: 16.05.2021).
2. Демянчук М.P. Профресійна комунікація майбутніх фрахівців сестринської справи. Психологія та педагогіка в системі сучасного гуманітарного знання XXI столітmя : матеріали міжнар. наук.-практ. конфр., м. Харків, 8-9 грудня 2017 р. Харків : Центр педагогічних досліджень, 2017. С. 53-55.

3. Децик О.3., Басараба Т.П. Вплив соціального, родинного та навчального оточення на фрормування превентивної обізнаності молоді щодо ВІЛ-інфекції. Україна. Здоров'я нації. 2016. № 1/2. С. 63.

4. Етичний кодекс медичної сестри України. URL: http://medmedsestrunstvo.blogspot.com/2016/03/blogpost_16.html (дата звернення: 03.05.2021).

5. Етичний кодекс профресійної етики міжнародної ради медсестер. URL: https://studopedia.info/5-31275. html (дата звернення: 22.05.2021).

6. Організація роботи медичної сестри 3 ВІЛінорікованими пацієнтами / Т.О. Кордис та ін. Медсестринство. 2017. № 3. С. 26-29.

7. Котова Н.В. ВІЛ-інфріковані діти: медичний догляд, психологічна підтримка, соціальний супровід, правовий захист. Київ : К.І.С., 2010. 176 с.

8. Кушлекайте М.І. Ставлення медичних сестер до ВІЛ-інфрікованих і хворих на СНІД. Соціологічні дослідження. 2006. № 5(265). С. 75-77.

9. Маркович О.В. Використання педагогічних технологій у процесі підготовки коледжами медичних сестер. Збірник наукових праць Інституту педагогіки і психології профресійної освіти АПН України. 2007. № 1. С. 64-70.

10. Низова Н.М., Талалаев К.А., Миронюк И.С. Роль первичного звена медико-санитарной помощи населению в системе противодействия ВИЧинорекции половым путем в Украине. Туберкульоз, легеневі хвороби, ВІЛ-інфрекція. 2013. № 4. С. 7-13.

11. Славопас В.А. Аналіз стану підготовки майбутніх медичних сестер засобами комп'ютерних технологій. Медична освіта. 2016. № 4. С. 59-61.

12. Талалаєв К.О. Від лікувальної допомоги до предиктивної медицини. Ознаки розвороту тренду. Вісник морської медицини. 2016. № 4. С. 7-11.

13. Шемшура А.Б., Городин В.Н., Зотов С.В. Роль сестринского персонала в реализации инновационного направления противодействия эпидемии ВИЧ-инорекции «Антиретровирусная терапия как профрилактика». Международный журнал экспериментального образования. 2015. № 11-6. С. 1004-1008. 